\title{
Infection factors related to nursing procedures in Intensive Care Units: a scoping review
}

\author{
Fatores de infecções relacionados aos procedimentos de enfermagem na Unidade de Terapia Intensiva: scoping review
}

Factores de infección relacionados con los procedimientos de enfermería en la Unidad de Cuidados Intensivos: revisión del alcance

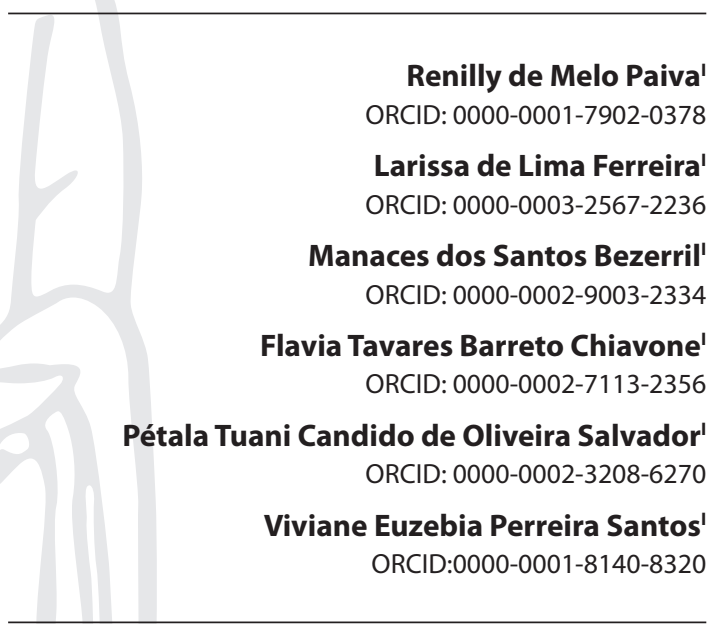

'Universidade Federal do Rio Grande do Norte. Natal, Rio Grande do Norte, Brazil.

How to cite this article: Paiva RM, Ferreira LL, Bezerril MS, Chiavone FTB, Salvador PTCO, Santos VEP. Infection factors related to nursing procedures in Intensive Care Units: a scoping review. Rev Bras Enferm. 2021;74(1):e20200731. doi: http://dx.doi.org/10.1590/0034-7167-2020-0731

\section{Corresponding author:}

Renilly de Melo Paiva

Email:renilly.melo@gmail.com

EDITOR IN CHIEF: Antonio José de Almeida Filho ASSOCIATE EDITOR: Priscilla Valladares Broca

Submission: $03-02-2020$

Approval: $10-03-2020$

\section{ABSTRACT}

Objectives: to identify and map the invasive procedures performed by nursing that can cause Healthcare-Associated Infections in patients in Intensive Care Units. Methods: this is a scoping review carried out in the first half of 2018, based on search for studies in national and international databases, in which 2,209 studies were found, of which 35 constituted the final sample. The data were analyzed and organized by simple descriptive statistics. Results: among the invasive procedures performed by nursing that provide Healthcare-Associated Infections, delayed bladder catheter was indicated in $34(66.67 \%)$ studies, the nasogastric catheter in $10(19.61 \%)$ and the nasoenteral catheter in two (03.92\%). Conclusions: in the face of such problems, better nursing planning and guidance for care in these invasive techniques becomes relevant and thus minimizes the incidence of infections.

Descriptors: Healthcare-Associated Infections; Intensive Care Units; Care; Nursing; Patients.

\section{RESUMO}

Objetivos: identificar e mapear os procedimentos invasivos executados pela enfermagem que podem ocasionar Infecções Relacionadas à Assistência em Saúde em pacientes na Unidade de Terapia Intensiva. Métodos: trata-se de uma scoping review, realizada no primeiro semestre de 2018, a partir da busca de estudos em bases de dados nacionais e internacionais, nas quais foram encontrados 2.209 estudos, dos quais 35 constituíram a amostra final. Os dados foram analisados e organizados por estatística descritiva simples. Resultados: dentre os procedimentos invasivos realizados pela enfermagem que propiciam Infecções Relacionadas à Assistência em Saúde, a sonda vesical de demora foi apontada em $34(66,67 \%)$ estudos, a sonda nasogástrica em $10(19,61 \%)$ e a sonda nasoenteral em dois $(03,92 \%)$. Conclusões: diante de tal problemática, torna-se relevante um melhor planejamento e orientação da enfermagem para o cuidado nessas técnicas invasivas e, assim, minimizar a incidência de infecções.

Descritores: Infecções Relacionadas à Assistência em Saúde; Unidades de Terapia Intensiva; Cuidado; Enfermagem; Pacientes.

\section{RESUMEN}

Objetivos: identificar y mapear los procedimientos invasivos realizados por enfermería que pueden ocasionar Infecciones Relacionadas con la Salud en pacientes en la Unidad de Cuidados Intensivos. Métodos: se trata de una revisión de alcance, realizada en el primer semestre de 2018, con base en la búsqueda de estudios en bases de datos nacionales e internacionales, en la que se encontraron 2.209 estudios, de los cuales 35 constituyeron la muestra final. Los datos fueron analizados y organizados mediante estadística descriptiva simple. Resultados: entre los procedimientos invasivos realizados por enfermería que brindan Infecciones Relacionadas con la Atención de la Salud, se indicó el catéter vesical retardado en $34(66,67 \%)$ estudios, el catéter nasogástrico en $10(19,61 \%)$ y el catéter nasoenteral en dos $(03,92 \%)$. Conclusiones: ante tales problemas cobra relevancia una mejor planificación y orientación de la enfermería para el cuidado en estas técnicas invasivas, minimizando así la incidencia de infecciones.

Descriptores: Infecciones Relacionadas con la Asistencia Sanitaria; Unidades de Cuidados Intensivos; Cuidado; Enfermería; Pacientes. 


\section{INTRODUCTION}

Currently, Healthcare-Associated Infections (HAIS) are considered a global health problem, due to rising hospital costs and morbidity and mortality rates ${ }^{(1)}$.

These consequences occur due to the length of hospital stay, the high rate of invasive procedures, both diagnostic and therapeutic, the severity of the underlying disease, the site of infection and the sensitivity to the antibiotics used ${ }^{(2-3)}$.

With that being said, a survey ${ }^{(1)}$ found that of the 1,048 patients admitted to an Intensive Care Unit (ICU), about $17.65 \%$ had infectious events such as ventilation-associated pneumonia (VAP), urinary tract infection (UTI) related to bladder catheterization and primary bloodstream infection linked to the central catheter.

Thus, it is clear that HAIS are associated with several factors, including invasive procedures, namely: insertion of central and/or peripheral venous catheters, bladder catheters (BCC), mechanical ventilation, tracheal aspiration, wound care, chest tube removal, among others ${ }^{(4-5)}$.

Among these techniques are those performed by nursing, which are performed with high frequency according to patients needs, presenting diagnostic and/or therapeutic purposes, in order to contribute to their recovery ${ }^{(4,6-8)}$.

Thus, it becomes pertinent to identify the risk factors that contribute to the development of HAIS, associated with invasive procedures performed by nurses in ICUs, in order to encourage measures that may reduce the incidence of HAIS damage and impairment, and, therefore, reduce the number of adverse events $(A E)$ and mortality due to $A E$.

Therefore, this study has the guiding question: which invasive procedures performed by nursing can cause HAIS in patients in ICUs and how does it occur?

\section{OBJECTIVES}

To identify and map the invasive procedures performed by nursing that can cause Healthcare-Associated Infections in patients in Intensive Care Units.

\section{METHODS}

\section{Ethical aspects}

There was no need for ethical assessment because the material used is in the public domain and does not involve human beings.

\section{Type of study}

This is a scoping review, with a protocol registered in the Open Science Framework (DOI 10.17605/OSF.IO/ZMUQ4), structured according to the international guide PRISMA-ScR recommendations ${ }^{(9)}$ and the Joanna Briggs Institute, Reviewers Manual method ${ }^{(10-11)}$, using a theoretical framework based on Arsey and O'Malley.

This investigation is based on an exploratory review which aims to map content associated with the theme investigated and point out gaps in the literature. It is described in five stages: I - research question formulation; II - identification of relevant studies; III - selection of studies; IV - data analysis; V - data synthesis and presentation ${ }^{(10)}$.

\section{Methodological procedures}

\section{Research question development}

For the first stage, the research question, the study objective and the descriptors were listed according to $\mathrm{PCC}^{(10)}$ mnemonic combination: $\mathrm{P}$ (Population) - Patients; C (Concept) - Nursing Care; $\mathrm{C}$ (Context) - Intensive Care Unit. The following guiding question emerged: what invasive procedures performed by nursing can cause HAIS in patients in ICUs and how does this occur?

\section{Data source}

Data collection was performed in January 2018 by searching the databases: PubMed, CINAHL, Web of Science, SCOPUS and LILACS; in the portals: Catalog of Theses and Dissertations from the Coordination for the Improvement of Higher Education Personnel (CAPES - Coordenação de Aperfeiçoamento de Pessoal de Nível Superior), Europe E-theses Portal (DART), Eletronic Theses Online Service (EThOS), Scientific Open Access Repository of Portugal (RCAAP), South African National Theses and Dissertations (ETD Portal) and Theses Canada; in gray literature through the journals: American Journal of Infection Control, Infection Control Hospital Epidemiology and Journal of Hospital Infection; and also at the National Health Surveillance Agency (ANVISA) and PROQUALIS.

The combination of the keywords Patients and Cross infection AND Nursing care AND Intensive care units occurred based on the particularities of each of the data sources presented. Although it maintained the grouping of similar keywords, it is also noteworthy that the investigation of the material occurred with the application of the Federated Academic Community (CAFe), authenticated by Universidade Federal do Rio Grande do Norte (UFRN).

\section{Data selection}

To select the studies and sample composition, Boolean operators AND and OR were used, as described in the search strategy: (Patients AND cross infection OR nosocomial infection) AND (Nursing care OR critical care Nursing OR Nursing protocols OR evidence -based nursing OR Nursing interventions OR pratice guideline) AND (intensive care units OR critical care).

The following inclusion criteria were defined: studies published in full in Portuguese, Spanish or English; that dealt with invasive procedures performed by nursing as possible HAIS factors in ICUs; manuals and protocols published by regulatory agencies. As for exclusion: duplicate searches; editorials; experience reports; theoretical essays; reflection studies; books; other revisions. It should be noted that there was no temporal delimitation. Figure 1 presents the selection process synthesis.

\section{Data analysis and organization}

The selected studies were observed regarding the type of material, study method, year of publication, country of origin, population and invasive procedure performed by nursing. The results (step V) were organized by simple descriptive statistics (relative and absolute), presented in graphs and/or table if discussed with literature support. 


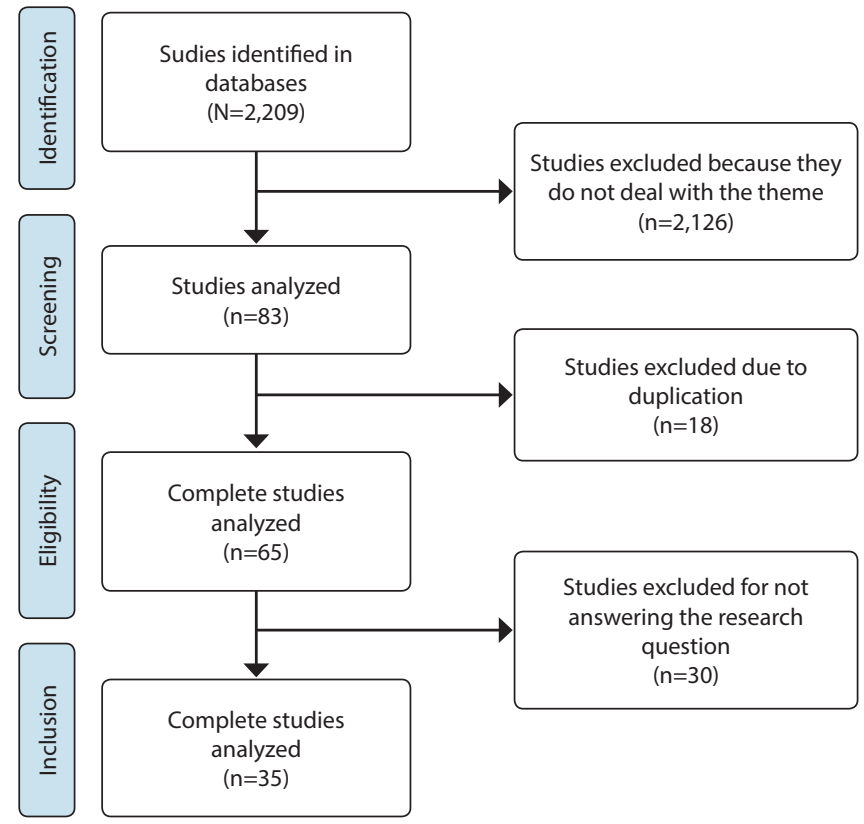

Figure 1 - Study selection steps, Natal, Rio Grande do Norte, Brazil, 2020

\section{RESULTS}

From an analysis of the 2,209 studies identified in the initial search, only 35 (100.0\%) were about the theme addressed, corresponding to the final sample. Of these, 30 (85.71\%) were articles, two $(05.71 \%)$ were dissertations, one $(02.87 \%)$ was a thesis and two $(05.71 \%)$ were manuals. It was noted that the years 2007,2010, 2012, 2013, 2016 and 2017 stood out with three (08.57\%) publications in each one (Figure 2).

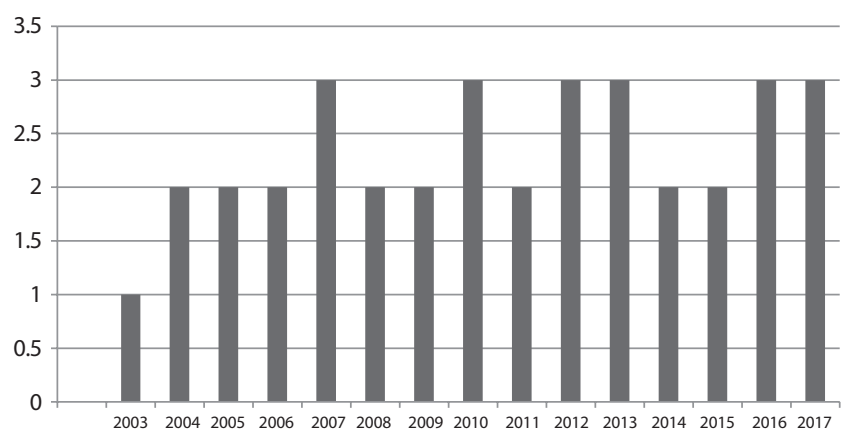

Figure 2 - Year of publication of studies, Natal, Rio Grande do Norte, Brazil, 2020, $(n=35)$

In relation to the countries of origin of the studies, Brazil stood out with eight (22.86\%), Serbia with four (11.43\%), Italy, Australia and Taiwan with three (08.57\%), Turkey with two (05.71\%) followed by Germany, Slovenia, USA, Finland, France, Greece, India, Republic of Ireland, Jamaica, Portugal, United Kingdom and Republic of Korea with one $(02.86 \%)$.

The approach used in the 35 (100.0\%) studies (articles, theses, and dissertations) was quantitative. As for the methodological design, it was shown descriptive in 10 (30.30\%) studies, casecontrol in nine (27.27\%), cohort in seven (21.21\%), cross-sectional in two $(06.06 \%)$ and observational in five $(15.15 \%)$. Concerning the level of evidence, level III was the most used, with 21 (63.64\%) publications, and then level IV, with 12 (36.36\%).
Among the invasive procedures performed by nursing that can cause HAIS in ICU patients, BCC is indicated in 34 (66.67\%) studies, the nasogastric tube (NGT), in 10 (19.61\%) and the nasoenteral tube (NET), in two (03.92\%). The main findings of research related to infections linked to invasive procedures are in Chart 1.

Chart 1 - Main findings of studies regarding invasive procedures as possible causes of infection, Natal, Rio Grande do Norte, Brazil, 2020, ( $n=33$ )

\begin{tabular}{|l|l|}
\hline $\begin{array}{l}\text { Invasive } \\
\text { procedure }\end{array}$ & Main findings related to the procedure* \\
\hline Bladder \\
catheters & $\begin{array}{l}\text { - Urinary tract infections associated with the catheter } \\
\text { about } 3.87 \text { infections per 1,000 days of use; } \\
\text { - Pseudomonasaeruginosa was the most common } \\
\text { organism in urinary tract infections associated with } \\
\text { the catheter; } \\
\text { - Considered as a risk factor for urinary tract } \\
\text { infections acquisition and blood flow; } \\
\text { - Significant risk factor for imipenem-resistant } \\
\text { Acinetobacter baumannii infections; } \\
\text { - Extended bladder catheters stay and use time; } \\
\text { - Urinary tract infections is related to the working } \\
\text { time of nursing professionals. }\end{array}$ \\
\hline $\begin{array}{l}\text { The nasogastric } \\
\text { tube }\end{array}$ & $\begin{array}{l}\text { - Significant risk factor for Acinetobacter baumannii } \\
\text { - Considered an extrinsic risk factor acquired in a } \\
\text { hospital environment; } \\
\text { - Risk factor for cross infection. }\end{array}$ \\
\hline Nasoenteral tube & $\begin{array}{l}{ }^{\prime} \text { More than one procedure was present in the same study. } \\
\text { - Risk factor for cross infections. }\end{array}$ \\
\hline
\end{tabular}

Although total parenteral nutrition (TPN) is not a procedure, it has been observed in studies as a risk factor for bloodstream infection (BSI) acquisition because it is necessary to install it intravenously.

\section{DISCUSSION}

The articles developed between 2007 and 2017 show the progress of the discussion about HAIS; therefore, they showed the development of programs and guidelines on the theme, in an attempt to assess $\mathrm{HAl}$ control and prevention in hospital settings, as with the creation of the Brazilian National Commission for Healthcare-Associated Infection Prevention and Control (CNIRAS - Comissão Nacional de Prevenção e Controle de Infecção Relacionada à Saúde) by Ordinance $1218 / 12^{(12)}$.

In relation to the countries that published the most, Brazil stood out due to studies ${ }^{(5,13)}$ pointing to the expressive occurrence of HAIS in national ICUs and for being understood as a public health concern.

As for the methodological designs used, the highest quantitative was the descriptive, which indicates the need for studies with greater methodological impact, such as experimental ones ${ }^{(11)}$.

Regarding invasive procedures, BCC stood out because it is one of the most performed in ICU based on the following guidelines: management of urinary retention, strict control of diuresis, measurement of diuresis for diagnostic tests, surgical and postoperative procedures, handling of immobilized people, neurogenic bladder carriers, terminally ill comfort, among others ${ }^{(14)}$.

Furthermore, due to $\mathrm{BBC}$ use time prolongation due to the severity of patients' clinical conditions and the indications mentioned above, patients have a high propensity to develop UTI ${ }^{(8,14)}$. 
That said, a study ${ }^{(13)}$ carried out in a clinical center in Serbia points out that the bacterium Pseudomona aeroginosa is the main cause of UTI, which causes intense infections due to its multidrug resistance to antibiotics, as well as IRAB ${ }^{(15)}$. Such complications are aggravated according to the risk factors: male gender, bladder catheterization length before UTI, intra-hospital reinfection, previous penicillin use and length of hospital stay ${ }^{(15-16)}$.

Thus, in order to prevent/reduce the number of HAIS, nursing has tools to optimize the performance of BCC, such as institutional protocols, which facilitate and guide the procedure, by indicating appropriate equipment and appropriate measures according to patient, in addition to the order of actions to be taken ${ }^{(17)}$.

Another factor that contributes to nursing work, minimizing the risk of UTI is the quality of their records, which aim to enhance communication between multidisciplinary staff members through registration of the material used, date of insertion and removal of the probe and the volume of urine drained ${ }^{(18-19)}$.

Regarding NGT and NET, it was realized that they are possible ways to acquire infections, by providing a gateway for the growth of microorganisms in the gastrointestinal tract and being a reservoir for pathogens resistant to antibiotics ${ }^{(20)}$.

The practice of such procedures is due to the fact that some of patients in intensive care have nutritional depletion or inability to swallow due to orotracheal tube (OTT) or tracheal tube (TCT) use so that performing NGT and/or NET serves to meet nutritional needs, perform gastric drainage, collect material for examination and administer medications ${ }^{(21-22)}$.

With regard to nursing activities towards NGT and NET, there is control of nutrition by promoting the introduction, maintenance, route of choice and adequate volume in the prevention of complications. As in performing the BCC, nurses have Standard Operating Procedures (PCOS) as devices to optimize the effectiveness of the activity and reduce the chances of infection ${ }^{(17,23)}$.

However, the scientific literature ${ }^{(22)}$ indicates negligence in hand hygiene as a risk factor for cross infection in NGT and/or NET insertion. Although the WHO indicates the five moments of this practice, to be included before performing the aseptic procedure, it is noted that nursing professionals do not comply with it correctly ${ }^{(24-25)}$.

Another risk factor for HAls in ICUs was TPN installation and maintenance, which may favor bloodstream infection, as it is associated with the use of a central catheter. Thus, it is necessary to use appropriate techniques for its handling and passage through exclusive venous access in order to avoid infections ${ }^{(25)}$.

Thus, it is understood that nursing must have adequate knowledge for care, especially in ICUs, due to the clinical complexity of patients and greater attention in carrying out numerous invasive procedures $^{(26-28)}$.
It is worth mentioning that it is up to the nurse, as a member of the health staff, and to the other multidisciplinary health staff members to participate in elaborating measures for prevention and systematic control of damages that may be caused to patients during assistance. Furthermore, they must implement and assess infection control programs and protocols in order to reduce HAl incidence and ensure patient safety. This will be achieved with the help of an updated educational process, adapted to the staff's needs ${ }^{(29)}$.

\section{Study limitations}

As limitations of the research, there is the restriction of the investigated sector and the professional category. HAls are a problem evidenced in several areas and health services, in addition to involving the different profiles of health workers.

\section{Contributions to nursing}

It is observed that identifying the main risk factors for HAIS can contribute to developing preventive measures and training in the care environment, and thus, minimizing the incidence of preventable infections in ICU settings. Moreover, it can promote discussions in the scientific and educational scope, as it provokes other research with similar themes and associates this content with patient safety in the classroom, respectively.

\section{CONCLUSIONS}

Among the invasive techniques practiced by nursing and considered as risk factors for HAls in patients admitted to ICUs, BCC, NGT and NET stood out.

In relation to the main reasons that cooperate for such techniques to be risk factors, there is pharmacological resistance to antibiotics, prolonged hospital stay and use of the inserted device, non-use of protocols, poor hand hygiene and the wrong way of performing activities.

Thus, there is a suggestion for carrying out future research the need for comprehensive HAls research for numerous hospital sectors and other professional categories due to the possible occurrence in several services and health sectors, in addition to the other workers performing procedures that can favor such infection.

\section{FUNDING}

Coordination for the Improvement of Higher Education Personnel (CAPES).

National Council for Scientific and Technological Development (CNPq).

\section{REFERENCES}

1. Rodrigues $C N$, Pereira DCA. Infecções relacionadas à assistência à saúde, ocorridas em uma Unidade de Terapia Intensiva. Rev Investig Biomédica[Internet] 2016 [cited 2018 Mar 07];8(1):41-51. Available from: http://www.ceuma.br/portalderevistas/index.php/RIB/article/ view/28/27

2. Hespanhol LAB, Ramos SCS, Ribeiro Jr OC, Araujo TS, Martins AB. Infecção relacionada à Assistência à Saúde em Unidade de Terapia Intensiva Adulto. Enferm Glob. 2019[cited 2018 Mar 07];53(1):229-41. Available from: https://revistas.um.es/eglobal/article/view/ eglobal.18.1.296481 
3. Silva PLN, Aguiar ALC, Gonçalves RPF. Relação de custo-benefício na prevenção e no controle das infecções relacionadas à assistência à saúde em uma Unidade de Terapia Intensiva Neonatal. Rev Saúde Ciênc Biol[Internet]. 2017 [cited 2018 Mar 07];5(2):142-9.Available from: http://revistaopiniaojuridica.unichristus.edu.br/index.php/jhbs/article/view/1195/421

4. Souza ES, Belei RA, Carrilho CMDM, Matsuo T, Ogatta SFY, Andrade G, et al. Mortalidade e riscos associados a infecção relacionada à assistência à saúde. Texto Contexto Enferm. 2015;24(1):220-8. doi: 10.1590/0104-07072015002940013

5. Sousa MAS, Nascimento GC, Bim FL, Oliveira LB, Oliveira ADS. Infecções hospitalares relacionadas a procedimentos invasivos em unidades de terapia intensiva: revisão integrativa. Rev Prevenç Infec Saúde[Internet] 2017 [cited 2018 Mar 07];3(3):49-58.Available from: http://www. ojs.ufpi.br/index.php/nupcis/article/view/4251/pdf

6. Puntillo KA, Max A, Timsit JF, Vignoud L, Chanques G, Robleda G, et al. Determinants of procedural pain intensity in the intensive care unit: Europain study. Am J Respir Crit Care Med [Internet]. 2014 [cited 2018 Mar 07];189(1):39-47. Available from: https://www.atsjournals.org/ doi/abs/10.1164/rccm.201306-11740C\#readcube-epdf

7. Ministério da Saúde (BR). Portaria n॰ 895. Institui o cuidado progressivo ao paciente crítico ou grave com os critérios de elegibilidade para admissão e alta, de classificação e de habilitação de leitos de terapia intensiva adulto, pediátrico, UCO, queimados e cuidados intermediários adulto e pediátrico no âmbito do Sistema Único de Saúde - SUS. Brasília, DF. [Internet] 2017 [cited 2018 Mar 07]. Available from: http://www.sgas.saude.ms.gov.br/wp-content/uploads/sites/105/2016/08/Portaria_895_2017_UTI_UCO.pdf

8. Sousa AFL, Oliveira LB, Moura MEB. Perfil epidemiológico das infecções hospitalares causadas por procedimentos invasivos em unidade de terapia intensiva. Rev Prevenç Infec Saúde[Internet] 2016 [cited 2018 Mar 07];2(1):11-7. Available from: http://www.ojs.ufpi.br/index.php/ nupcis/article/view/6048/pdf

9. Tricco AC, Lillie E, Zarin W, O'Brien KK, Colquhoun H, Levac D, et al. PRISMA Extension for Scoping Reviews (PRISMA-ScR): checklist and Explanation. Ann Intern Med. 2018;169(7):467-73. doi: 10.7326/M18-0850

10. Arksey H, O'Malley L. Scoping studies: towards a methodological framework. Int J Soc Res Methodol. 2005;8(1):19-32. doi: 10.1080/1364557032000119616

11. Joanna Briggs Institute. Reviewer's manual: 2014 edition. Adelaide, Austrália: JBI; 2014.

12. Oliveira HM, Silva CPR, Lacerda RA. Políticas de controle e prevenção de infecções relacionadas à assistência à saúde no Brasil: análise conceitual. Rev Esc Enferm Usp. 2016;50(3):505-11 doi: 10.1590/S0080-623420160000400018

13. Silva TF, Morais MMCA. Perfil de IRAS em um hospital do sudoeste do brasil. J Infect Control[Internet]. 2017 [cited 2018 Mar 07];6(4):1-14 Available from: http://jic.abih.net.br/index.php/jic/article/view/191

14. Coelho IR, Silva HD. Uso de cateter vesical de demora entre pacientes internados na clínica cirúrgica de um hospital universitário. JCS HUUFPI [Internet]. 2018 [cited 2018 Mar 07];1(1):41-50 Available from: http://www.ojs.ufpi.br/index.php/rehu/article/view/6757/pdf

15. Silva DM, Menezes EMN, Silva EV, Lamounier TAC. Prevalência e perfil de suscetibilidade antimicrobiana de agentes patogênicos ESKAPE do distrito federal, Brasil. J Bras Patol Med Lab [Internet]. 2017 [cited 2018 Mar 07];53(4):240-5 Available from: http://www.scielo.br/pdf/jbpml/ v53n4/1676-2444-jbpml-53-04-0240.pdf

16. Djordjevic Z, Folic MM, Zivic Z, Markovic V, Jankovic SM. Nasocomial urinary tract infections caused by pseudomonas aeruginosas and acinetobacter species: sensitivity to antibiotics and risk factors. Am J Infect Control[Internet]. 2013[cited 2018 Mar 07];41(12):1182-7. Available from: https://www.sciencedirect.com/science/article/pii/S0196655313005932?via\%3Dihub

17. Chaves NMO, Moraes CLK. Controle de infecção em cateterismo vesical de demora em unidade de terapia intensiva. RECOM [Internet]. 2015[cited 2018 Mar 07];5(2):1650-7. Available from: http://seer.ufsj.edu.br/index.php/recom/article/view/773/867

18. Rojahn D, Souza I, Locatelli P, Hermann R, Ascari RA. Comunicação efetiva em registros de enfermagem: uma prática assistencial. Uningá Rev[Internet]. 2014 [cited 2018 Mar 07];19(2):9-13. Available from: http://revista.uninga.br/index.php/uningareviews/article/view/1540

19. Mazzo A, Bardivia CB, Jorge BM, Souza Jr VD, Fumincelli L, Mendes IAC, et al. Cateterismo urinário de demora: prática clínica. Enferm Glob [Internet]. 2015[cited 2018 Mar 07];14(38):60-8. Available from: http://scielo.isciii.es/pdf/eg/v14n38/pt_clinica3.pdf

20. Brado BCF, Zeitoun SS. Pneumonia associada à ventilação mecânica: avaliação do conhecimento da equipe de enfermagem de uma terapia intensiva. Arq Med Hosp Fac Cienc Med Santa Casa São Paulo [Internet]. 2017 [cited 2018 Mar 07];62(3):130-8. Available from: http:// arquivosmedicos.fcmsantacasasp.edu.br/index.php/AMSCSP/article/view/5/57

21. Anziliero F, Corrêa APA, Silva BA, Soler BED, Batassini E, Beghetto MG. Sonda nasoenteral: fatores associados ao delay entre indicação e uso em emergência. Rev Bras Enferm. 2017;70(2):344-52 doi: 10.1590/0034-7167-2016-0222

22. Melo EM, Barbosa AA, Silva JLA, Sombra RLS, Studart RMB, Lima FET, et al. Evolução clínica dos pacientes em uso de ventilação mecânica em unidade de terapia intensiva. REUOL [Internet]. 2015 [cited 2018 Mar 07];9(2):610-6. Available from: https://periodicos.ufpe.br/revistas/ revistaenfermagem/article/view/10379/11124

23. Campos FA, Caetano JÁ, Almeida PC, Silva VM. Terapia de nutrição enteral: construção e validação de protocolo. Rev Enferm UERJ [Internet]. 2016 [cited 2018 Mar 07];24(2):1-5. Available from: http://www.e-publicacoes.uerj.br/index.php/enfermagemuerj/article/view/11625/19415

24. Ferraz CCB, Ortega FB, Silva RB, Leite LRC, Hildebrand CR. Fatores associados a infecções hospitalares causadas por microorganismos multirresistentes num hospital de ensino. PECIBES [Internet]. 2016 [cited 2018 Mar 07];2(2):52-7 Available from: http://desafioonline.ufms. br/ojs/index.php/pecibes/article/view/1380/0 
25. Souza LM, Ramos MF, Becker ESS, Meirelles LCS, Monteiro SAO. Adesão dos profissionais de terapia intensiva aos cinco momentos da higienização das mãos. Rev Gaúcha Enferm [Internet]. 2015[cited 2018 Mar 07];36(4):21-8 Available from: http://www.seer.ufrgs.br/ RevistaGauchadeEnfermagem/article/view/49090

26. Costa P, Paiva ED, Kimura AF, Castro TE. Fatores de risco para infecção de corrente sanguínea associada ao cateter central de inserção periférica em neonatos. Acta Paul Enferm. 2016;29(2):161-8 doi: 10.1590/1982-0194201600023

27. Gonçalves EO, Lima MS, Melo JL, Pontes MSR, Sousa AOB, Albernaz MP. Práticas assistenciais de enfermagem e prevenção da pneumonia associada à ventilação mecânica em UTI. REUOL [Internet]. 2015 [cited 2018 Mar 07];9(12):1069-77 Available from: https://periodicos.ufpe. $\mathrm{br} / \mathrm{revistas} /$ revistaenfermagem/article/view/10809

28. Nogueira LS, Ferreti-Rebustini REL, Poveda VB, Silva RCG, Barbosa RL, Oliveira EM, et al. Carga de trabalho de enfermagem: preditor de infecção relacionada à assistência à saúde na terapia intensiva? Rev Esc Enferm USP[Internet]. 2015 [cited 2018 Mar 07];49(esp):36-42 Available from: http://www.scielo.br/pdf/reeusp/v49nspe/1980-220X-reeusp-49-spe-0036.pdf

29. Ministério da saúde (BR). Lei №. 7.498, de 25 de junho de 1986. Dispõe sobre a regulamentação do exercício da enfermagem, e dá outras providências [Internet]. Brasília; 1986 [cited 2018 Mar 07]. Available from: http://www.planalto.gov.br/ccivil_03/leis/l7498.htm 